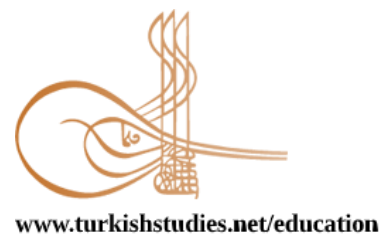

Turkish Studies - Educational Sciences

eISSN: 2667-5609

ResearchArticle / Araştırma Makalesi

\title{
Bilim ve Sanat Merkezlerinin Mezun ve Veli Gözüyle Değerlendirilmesi*
}

\author{
The Evaluation of Scienceand Art CentersAccordingtotheOpinions of GraduatesandTheirParents
}

\author{
Hayriye Torunoğlu** ${ }^{* *}$ Mehmet Taşdemir ${ }^{* * *}$
}

\begin{abstract}
In Turkey, science and art centers which were founded to provide special education to gifted students, have an important place in the education system. The aim of this study is to evaluate science and art centers in line with the opinions of graduates and their parents. The sample of the study consisted of graduates who graduated from these institutions and parents of graduates. The study was a qualitative study and the data were obtained by interview technique. In this study, 12 parents and 15 graduates were interviewed on a voluntary basis. The data of the research were collected through these interviews and analyzed by content analysis. The interview form prepared by the researcher was used as data collection tool. In the interviews, the expectations of SAC by the graduates and their parents, the contributions of SAC, the information program of SAC, the attendance status were evaluated and finally the participants offered suggestions for SAC to be more effective. According to the findings, parents and graduates stated that their expectations were met at a high level. It was observed that the expectations were mostly in preparation for the exam, education according to interests and abilities, self-development in thefield of art and social activity. It has been concluded that SAC have made a great contribution to students in the academic, personal and social development areas. It was found out that during the LGS and YGS exam periods, the exams were supplemented, the classical course was processed and the problems of absenteeism were experienced due to the exams. The reasons of absenteeism were concluded as; exam marathon, being busy, school exams, staying in boarding schools and high school attendance.
\end{abstract}

StructuredAbstract: Introduction: Science and Art Centers (SAC) were founded for the gifted in Turkey. The first one of SAC which was opened in 1995 in Ankara, serves today in almost all provinces. With the program implemented in SAC, it is planned to serve gifted students within the period outside of schools. Students can receive education without leaving their school life with the curriculum prepared according to school hours. While continuing their school education, it is ensured that they realize their talents and receive training to develop their talents. As seen in many researches about Science and Art centers, they were tried to be evaluated through students, parents and teachers. This study was carried out with the students graduated from Bilsem and their parents. In this study, it is based on the thesis that the people who will evaluate a process best are those who have completed that process. The aim of this study is to evaluate science and art

\footnotetext{
* Çalışmada kullanılan veriler 2019 yılında temin edilmiştir.

** Öğretmen, MEB

Teacher, Ministry of Education

ORCID 0000-0003-0802-6929

hayriyetorunoglu@gmail.com

${ }_{* * *}^{*}$ Prof. Dr., Ahi Evran Üniversitesi, Eğitim Fakültesi, Eğitim Bilimleri Bölümü

Prof. Dr., Ahi Evran University, Faculty of Education, Department of Educational Sciences

ORCID 0000-0002-5896-0587

mttasdemir1963@gmail.com

Cite as/ Atıf: Torunoğlu, H.\& Taşdemir, M.(2020). Bilim ve sanat merkezlerinin mezun ve veli gözüyle değerlendirilmesi. Turkish Studies-Education, 15(3), 2117-2136. https://dx.doi.org/10.29228/TurkishStudies.42252

Received/Geliş: 24 March/Mart 2020

Accepted/Kabul: 21 June/Haziran 2020

Checkedbyplagiarism software

Copyright (C) INTACLTD, Turkey

Published/Yayın: 25 June/Haziran 2020

CC BY-NC 4.0
} 
centers in line with the opinions of graduates and their parents. Science and Art Centers evaluated with different dimensions, it is aimed to reveal the positive and negative aspects of these institutions.

Method: The study is descriptive research and a case study using qualitative data collection techniques. In this study, the interview method was used to get the opinions of SAC graduates and their parents regarding the SAC process. The sample of the study consisted of graduates of these institutions and parents of graduates. The study was carried out with 15 graduates and 11 parents. The first group of the study consisted of 15 students who graduated from Kırşehir Yusuf Demir Science and Art Center. Students were selected randomly and interviews were conducted on a voluntary basis. 7 of the students were girls and 8 were boys. The second study group consists of parents whose children were graduated from the Science and Art Center. Interviews were made with 11 parents who were chosen randomly on a voluntary basis. The interview form consists of the personal information section where the demographic information of the individuals is requested and the second section including the interview questions. The interview form consists of 6 semi-structured questions. In the process of preparing questions, a question pool was created after the related literature was scanned. Interview questions were determined by choosing the questions that will serve the purpose of the study. Following the literature review in the development of the interview form used in the research, the prepared form was presented to the opinion of 5 experts with the options "suitable", "not suitable" and "your opinion about its correction". Then, in line with the feedback from the experts, instructions and articles were provided with clearness and clarity. After the expert opinion was taken, a pilot interview was held by making the necessary corrections in line with the suggestions from the experts. Qualitative data of the study were analyzed through categorical analysis, one of the content analysis methods. The opinions determined during the analysis of the data were analyzed and explained in certain themes / categories, taking into account the meaning of the participants. Accordingly, the opinions of the participants were grouped under a number of categories as a result of the analysis and the findings related to these categories were explained and supported by the original expressions of the participants. The data obtained by collecting the opinions of the graduates and parents through the semi-structured interview form were analyzed independently by two researchers and content analysis was carried out. In this process, the researchers independently examined the interview forms and categories were created based on the answers given for each question item.

Findings: Within the framework of the findings obtained regarding the fulfillment levels of expectations, it is seen that both parents and graduates are largely satisfied. It is seen that the students expect to get support for their exams. In addition, there were expectations expressed by the students about selfdevelopment in art, developing creative thinking, receiving education for their interests, having different experiences and developing their social skills. Although there are students who want to take reinforcement courses for exams from SACs during the exam periods, it can be said that there are also those who are uncomfortable with this situation. There are also students who want to take part in more projects and social activities instead of teaching during exam periods. When the suggestions of graduates and parents for the operation of SAC are examined during the exam periods, it is seen that all of the suggestions cover the high school period. Participants made suggestions to increase the number of courses in this period. Parents and graduates made different suggestions for the more effective functioning of BiLSEMs in the study. Two suggestions from both participant groups, namely "improving physical conditions and focusing on projects", have emerged in a common dimension. In the suggestions of participants for SAC to be more effective, parents state that there should be certain criteria in choosing teachers for these instutions.

Conclusion and Suggestions: Considering the evaluations of parents and students towards BILSEM, it is seen that both students and parents are mostly dissatisfied with the practices in high school period. It is seen that their expectations in primary and secondary schools are met, but there are many problems in high school. Social activities can be increased, and studies can be carried out for the needs of students on this subject. With the help of projects carried out with students, their scientific research knowledge and skills can be improved. Students can spend their high school period by carrying out projects and activities so that they can be more active and productive. SAC can give support to them to get away from the stress of the university exam and they can contribute more to their social development with the social activities they participate in.

Keywords: Science and art center (SAC), Graduate, Parents, Gifted and talented, gifted student education 
Öz: Türkiye'de özel yetenekli öğrencilere özel eğitim vermesi amaciyla kurulan Bilim ve Sanat Merkezleri, eğitim sisteminde önemli bir konuma sahiptir.Bu çalışmanın amacı Bilim ve Sanat Merkezlerinin etkinliğini bu kurumlardan mezun olmuş öğrenci ve velilerin görüşleri doğrultusunda değerlendirmektir. Çalışmanın örneklemini Bilim ve Sanat Merkezinde eğitimlerini tamamlamış mezun öğrenciler ve çocuğu bu kurumlardan mezun olmuş veliler oluşturmuştur. Çalışma nitel bir çalışma olup, veriler görüşme tekniği ile elde edilmiştir. Araştırmada gönüllülük esasına dayanarak 11 veli ve 15 mezun ile görüşmeler yapılmıştır. Araştırmanın verileri, bu görüşmeler yoluyla toplanmış ve veriler içerik analizi tekniği yoluyla çözümlenmiştir. Veri toplama aracı olarak araştırmacılar tarafından hazırlanan görüşme formu kullanılmıştır. Yapılan görüşmelerde, mezun ve velileri tarafından BİLSEM'den beklentiler, BİLSEM'in katkıları, BİLSEM programı, BİLSEM'e devam durumu değerlendirilmiş ve son olarak da katılımcılar BİLSEM'in daha etkin olması için öneriler sunmuşlardır. Çalışmadan elde edilen bulgulara göre, mezunlar ve velileri BİLSEM'e yönelik sahip oldukları beklentilerinin yüksek düzeyde karşılandığını belirtmişlerdir. BILLSEM'e yönelik beklentiler sınava hazırlık, ilgi ve yeteneklere göre eğitim, sanat alanında kendini geliştirme ve sosyal etkinlik ağırlıklı eğitim olarak ortaya çıkmıştır. BİLSEM'in akademik, kişisel ve sosyal gelişim alanlarında öğrencilere büyük katkı sağladığı sonucuna varılmıştır. LGS ve YGS sınav dönemlerinde öğrencilerin yaşadığı olumlu durumlar değerlendirildiğinde sınavlara takviye yapılması, olumsuz durumlar olarak ise klasik ders işlenmesi ve sınavlar nedeniyle devamsızlık sorunu gibi temalar ortaya çıkmıştır. BILLSEM'de devamsızlık nedenlerinin; sınav maratonu, yoğunluk, okul sınavları, yatılı okulda okumak ve lisede yaşanan devamsızlık sorunu olduğu sonucuna varılmıştır.

Anahtar kelimeler: Bilim ve Sanat Merkezi (BİLSEM), BİLSEM mezunu, Mezun velisi, Üstün yetenekli, Üstün yetenekli eğitimi

\section{Giriş}

Akranlarından zihinsel ve yetenek alanlarında daha yüksek bir performans sergileyen ya da sergileme potansiyeline sahip kişiler için üstün zekâlı (gifted) veya üstün yetenekli (highlytalented) kavramları kullanılmaktadır (Greenan vd., 1996; Chan,2001; MEB, 2013; Coleman vd., 2015; Poiner, 2018). Üstün yetenekli çocuklar, akranlarından iki temel yolla farklılık gösterirler: yetenek ve motivasyon. Öğrendikleri konu ne kadar yoğun ve gizil olursa, üstün yetenekli öğrencilerin yeteneklerini fark etmeleri için firsat artar (Coleman vd., 2015). Üstün yetenekli çocukları fark etmek için onların sahip olduğu farkl1lıkları gözlemleyebilmek önemli görülmektedir. Üstün yetenekli öğrenciler karmaşık fikirleri akranlarına göre daha çabuk kavrar ve derinlemesine öğrenirler. Akranlarının sahip olduğu ilgilerden çok farklı ilgiler sergileyebilirler. Derinlemesine araştırmalar için zamana ihtiyaç duyarlar. Fikirleri yönlendirirler, birbirleriyle bağlantısız görülen kavramlara ilişkin genellemelerde bulunur ve kışkırtıcı sorular sorabilirler (Bildiren, 2013).

Normal gelişim gösteren öğrenciler için hazırlanmış olan eğitim programları, üstün yetenekli öğrenciler için uygun olmamakta, hızlı öğrendikleri için okulda sıkılmakta ve bu nedenle motivasyonlarını kaybetmektedirler (Ataman, 2003). Özel yetenekliler yetenekleri doğrultusunda bir eğitim aldıkları durumlarda toplumların ilerlemelerine katkı sağladıkları gibi yeterince değerlendirilemedikleri durumlarda da toplumlar için risk oluşturmaktadırlar. Özel yetenekli çocukların yeteneklerinin erken yaşlarda keşfedilmesi eğitilmesi bu çocukların bireysel yaşantıları ve toplumsal yaşam standartlarının yükseltilmesi bakımından önemlidir (Hökelekli ve Gündüz, 2004). Bu nedenle üstün yetenekli öğrencilerin eğitimi için onların öğrenme hızına ve seviyelerine uygun eğitim programlarıyla eğitim almaları gerekmektedir.

Amerika'da ve dünyanın birçok ülkesinde üstün yetenekli kabul edilen çocukların eğitimi için farklılaştırılmış ve zenginleştirilmiş programlar uygulanmaktadır. ABD'de üstün yetenekliler için uygulanan eğitim programı, öğretmen eğitimlerinde kapsamlı hizmetler sunan, akademik yıl boyunca ve yaz aylarında okul bölgeleri için mesleki ve program geliştirme şeklinde saha içi ve çevrimiçi programlar aracılı̆̆ıyla öğrencilere doğrudan hizmet veren bir sisteme sahiptir. Ülke genelinde seçkin üniversitelerin ev sahipliğini yaptığı 20 üstün yetenekliler eğitim merkezi 
bulunmaktadır (Van-TasselBaska, 2018). Uygulanan programda hızlandırma, zenginleştirme, sınıf atlatma, ders farklılaştırma, küme yöntemleri uygulanmaktadır (Bildiren, 2013; Poiner, 2018).

Üstün yeteneklilerin eğitimi konusundaki çalışmalarında önde gelen ülkelerden biri de Avustralya'dır. Avustralya'da, üstün yetenekli öğrenciler için bağımsız sınıflar ve okullar sunan çok sayıda okul ve eğitim sistemi vardır. Özel okullar müzik ve zihinsel alanlarda üstün yetenekli öğrenciler için kendi programlarını geliştirme hakkına sahiptirler. Erken yaşta keşfedilen üstün yetenekli çocuklar iki yıl süreyle okulöncesi döneminde özel eğitime alınmaktadır (Walsh ve Jolly, 2018).

Türkiye'de önceki y1llarda üstün zekâlı ya da üstün yetenekli olarak kullanılan kavramlar MEB (2013) tarafından "üstün zekâ" ve "üstün özel yetenek" kavramları "üstün yetenek" başlı̆̆1 altında toplanmıştır. Üstün yetenekliler, genel ve/veya özel yetenekleri açısından yaşıtlarına göre yüksek düzeyde performans gösterdiği konunun uzmanları tarafından belirlenmiş kişiler olarak tanımlamıştır. Özel yetenekli birey kavramı da zekâyı ve yeteneği bir arada bulunduran bir kavramdır. Özel yetenek kavramı genel zihinsel yetenek, özel akademik yetenek, dil, matematik, fen bilimleri, sosyal bilimler, liderlik, yaratıc1lik, görsel ve işitsel sanatlar ve psikomotor becerileri kapsamaktadır (MEB, 2013).

Türkiye'de üstün yeteneklilerin kendilerine uygun eğitimi almaları için Bilim ve Sanat Merkezleri (BİLSEM) kurulmuştur. İlki 1995 yılında Ankara'da açılan BİLSEM bugün neredeyse bütün illerde hizmet vermektedir. Bu merkezler çocukların hem bilim hem de sanat alanında eğitim aldıkları kurumlar olmuştur (Tebliğgler Dergisi, 2001).BİLSEM, Milli Eğitim Bakanlığı'nın Özel Eğitim ve Rehberlik Hizmetleri Genel Müdürlüğü bünyesinde, üstün yetenekli çocukların bilim ve sanat alanında eğitimi amacıyla kurulmuştur. Bağımsız eğitim kurumları olan bu merkezlerde okul öncesi, ilköğretim ve ortaöğretim çağındaki özel yetenekli öğrencilerin belirlenmesi ve yetenek alanlarına uygun eğitim almaları ile ilgili çalışmalar yürütülmektedir (MEB, 2007). BİLSEM'de uygulanan programla özel yetenekli öğrencilere örgün eğitim aldıkları okulları dışındaki sürede hizmet vermesi planlanmıştır. Öğrenciler okul yaşamlarından ayrıştırılmadan, okul saatlerine uygun şekilde hazırlanan ders programlarıyla eğitim alabilmektedirler. Okul eğitimlerine devam ederken bir yandan da yeteneklerini fark etmeleri ve bu yeteneklerinin geliştirilmesine yönelik eğitim almaları sağlanmaktadır.

BİLSEM sınav süreci 3 aşamadan oluşmaktadır. Bunlardan ilki sınıf öğretmeninin uygun gördügü öğrencileri aday göstermesidir. Aday gösterilen öğrenciler sınav başvurusunun ardından Bakanlıkça belirlenen ölçme araçları ile sınava alınırlar.Tanılama takvimi süreci içerisinde, grup taramasında belirlenen ölçütte ya da üzerinde performans gösteren öğrencilerin listesi Bakanlıkça il tanılama sınav komisyonuna gönderilir. İl tanılama sınav komisyonu tarafından Bakanlıkça belirlenen ölçütler doğrultusunda, objektif ve standart ölçme araçları ile öğrencilerin bireysel incelemesi yapılır (MEB, 2018). Bireysel incelemeyi başarıyla geçen öğrenciler kayıt hakkı kazanmış olurlar.

Özel yetenekli öğrencilerin eğitim ilkelerinde yer alan hızlandırma, gruplandırma, farklılaştırma ve derinleştirme kriterlerine göre etkinlikler planlanır ve uygulanır. Uygulamada müfredat zenginleştirmeleriyle öğrencilerin yaratıcılıkları geliştirilmeye çalışılmakta, ayrıca öğrencilerin bir bütün olarak gelişmeleri hedeflenerek duygusal ve sosyal yönden gelişmelerini sağlayacak etkinlikler müfredatla bütünleştirilmektedir. BİLSEM'lerde yapılan etkinliklerin temelinde proje üretme ve geliştirme çalışmaları yatar. Yöntem olarak öğretmenlerin öğrenciye öğretmesi yerine, öğrencilerin kendi belirleyecekleri projeler içinde kendi çözümlerini uygulamaları ve süreç içinde ilgili konuyu öğrenmeleri modeli uygulanır. Yönergede şu bölümlere ilişkin açıklamalara yer verilmiştir: Bilim ve Sanat merkezlerinin amaçları ve ilkeleri, Bilim ve Sanat Merkezlerinin işleyiş ve görevleri, tanılama ve yerleştirme, eğitim-öğretim ve uygulama. (MEB, 2018). 
Bilim ve Sanat Merkezlerinde öğrenciler beş aşamalı programa tabi tutulur.

1. Uyum,

2. Destek Eğitimi (İletişim Becerileri, Bilimsel Çalışma Yöntemleri, Bilgisayar, Yabancı Dil, Problem Çözme Teknikleri, Grupla Çalışma Teknikleri, Öğrenme Yöntemleri, Sosyal Etkinlikler, Araştırma Teknikleri)

3. Bireysel Yetenekleri Fark Ettirme

4. Özel Yetenekleri Geliştirme

5. $\quad$ Proje Üretimi

Bilim ve Sanat Merkezleri kuruldukları günden bu yana birçok araştırmanın konusu olmuştur. Çalışmalarda farklı açılardan değerlendirmeler yapılmış ve BİLSEM kurumları incelenmiştir (Karakuş, 2010;Yıldız 2011; Yumuş ve Toptaş, 2011; Kazu ve Şenol, 2012; Kaya, 2013; Keskin vd., 2013; Sar1 ve Öğülmüş, 2014; Şahin, 2014; Bedur vd., 2015; Çavuşoğlu ve Semerci, 2015; Sarıtaş vd., 2019). Çalışmalar genellikle veliler, öğretmenler ve öğrencilerle yürütülmüştür.

Bilim ve Sanat Merkezlerine ilişkin yapılan birçok araştırmada görüldüğü gibi BİLSEM ler öğrenci, veli ve öğretmenler aracılığı ile değerlendirilmeye çalıșılmıștır. Bu çalıșma bir süreci en iyi değerlendirecek kişilerin o süreci tamamlamış olan kişiler olduğu tezinden yola çıkarak bu çalışmada BİLSEM'de eğitim almış ve mezun olmuş öğrenciler ve onların velileri ile yürütülmüştür. Süreci ve programı en objektif şekilde değerlendirecekleri konusundan hareketle yola çıkılmıştır. Çalışmada BİLSEM'ler çok boyutlu olarak değerlendirilmeye çalışılmıştır. İlgili alan yazında mezunlarla ve mezun velileri ile yapılan bir çalışma bulunmadığından, çalışma bu yönüyle bir ilk olma özelliği taşımaktadır. BİLSEM eğitim programlarının hepsini tamamlamış olmaları nedeniyle, BİLSEM'i bir bütün olarak değerlendirmek amaçlanmıştır. Çalışma, BİLSEM'i yalnız bazı programları tamamlamış öğrenci, onların velileri ya da belli sınıf kademelerinde eğitim veren öğretmenler ile yürütülen çalışmalardan bu yönüyle de ayrılmaktadır. Elde edilen bulgular 1şığında alan uzmanlarına ve alan yazına katkı sağlanacağı düşünülmektedir.

Çalışmada aşağıdaki sorulara yanıt aranmıştır:

1. BİLSEM'den mezun öğrenci ve veli beklentileri nelerdir?

2. BİLSEM öğrencilerine hangi boyutlarda katkı sağlamaktadır?

3. BILLSEM'e devam sürecinde karşılaşılan güçlükler nelerdir?

4. BİLSEM'de sınav dönemlerinde karşılaşılan güçlükler nelerdir?

5. BILLSEM'de uygulanan eğitim programına ilișkin mezun ve veli değerlendirmesi nedir?

6. BİLSEM'in etkinliğinin artırılmasına dönük mezun ve veli önerileri nedir?

\section{Yöntem}

\section{Araştırma Modeli}

Araştırmada tarama modeli kullanılmıştır. Tarama modelinde, bilinmek istenen açık ve meydandadır. Amaç o şeyi doğru bir şekilde gözlemleyip belirleyebilmektir. Asıl amaç değiştirmeye kalkmadan gözlemektir (Karasar, 1984). Bilim ve Sanat Merkezlerini farklı boyutlarıyla ele alan bu çalışmada, bu kurumların olumlu ve olumsuz yönlerinin ortaya konması amaçlanmıştır. Çalışma betimselbir araştırmadır ve nitel veri toplama tekniklerinin kullanıldığ 1 bir durum çalışmasıdır. Nitel araştırmada durum çalışması, bir olayın yoğun bir şekildeçalışılmasıyla ilgilidir (Glesne, 2012). Bu çalışmadadurum çalışması yaklaşımı benimsenmiş olup, görüşme yolu 
ile veri toplama işlemi gerçekleştirilmiştir. Briggs (1986, akt. Yıldırım ve Şimşek, 2013) görüşmenin sosyal bilimler alanında yapılan araştırmalarda kullanılan en yaygın veri toplama yöntemi olduğunu savunmakta ve bu durumun, görüşme yönteminin; bireylerin deneyimlerine, tutumlarına, görüşlerine, şikâyetlerine, duygularına ve inançlarına ilişkin bilgi elde etmede oldukça etkili bir yöntem olmasından kaynaklandığını belirtmektedir. Bu çalışmada BİLSEM mezunlarının ve velilerinin BİLSEM sürecine ilişkin görüşlerini almak amacıyla görüşme yöntemi kullanılmıştır.

\section{Çalışma Grupları}

Araştırma iki farklı grupla yürütülmüştür. Bilim ve Sanat Merkezlerinin çok boyutlu olarak incelendiği bu çalışmada Bilim ve Sanat Merkezlerine ilişkin görüşler bu kurumlardan mezun olan öğrenci ve çocuğu bu kurumlardan mezun olan velilerden elde edilmiştir. Çalışma grubunu nitel araştırma örnekleme yöntemlerinden amaçlı örnekleme yoluyla belirlenmiştir. Amaçlı örnekleme yöntemleri pek çok durumda olgu ve olayların keşfedilmesinde ve açıklanmasında yararlı olur (Yıldırım ve Şimşek, 2013). Amaçlı örnekleme yöntemlerinden ölçüt örnekleme esas alınmıştır. Ölçüt örnekleme yöntemindeki temel anlayış önceden belirlenmiş bir veya birden fazla ölçütü karşılayan bütün durumların çalışılmasıdır (Yıldırım ve Şimşek, 2013). Görüşme yapılan öğrencilerin BİLSEM mezunu olmaları ölçüt olarak alınmıştır. Devamsızlık nedeniyle BİLSEM eğitimlerini yarım bırakmış olan öğrenciler çalışmaya dahil edilmemiştir. Aynı şekilde görüşme yapılan velilerin de çocukları BILLSEM eğitimlerini tamamlamıştır. Gönüllülük esasına dayanarak oluşturulan çalışma grubunu 15 mezun öğrenci ve 12 veli oluşturmuştur. Aşağıda sırasıyla mezun öğrenci ve velilere ilişkin demografik bilgiler verilmiştir.

\section{Çalışma Grubu 1 (Mezun Öğrenciler)}

Çalışmanın birinci grubunu Kırşehir Yusuf Demir Bilim ve Sanat Merkezi’nde öğrenim görmüş ve mezun olmuş 15 öğrenci oluşturmuştur. Öğrenciler random yolla seçilmiş olup, görüşmeler gönüllülük esasına dayanarak yapılmıştır. Öğrencilerin 7'si kız, 8'i erkeklerden oluşmuştur. Öğrencilerin 1'i Resim alanında, 2'siMüzik alanında ve 12 öğrenci genel Zihinsel Yetenek Alanında eğitim görmüşlerdirAraştırmada yer alan mezun öğrencilerin cinsiyet ve BİLSEM'de eğitim gördükleri alanlara ilişkin bilgiler tablolaştırılarak verilmiştir.

Tablo1: Mezun Öğrencilerin Cinsiyete Göre Dağılımı

\begin{tabular}{lc}
\hline Cinsiyet & $f$ \\
\hline Kiz & 7 \\
Erkek & 8 \\
Toplam & 15 \\
\hline
\end{tabular}

Öğrencilerin 7'si kız, 8'i erkeklerden oluşmuştur.

Tablo 2: Mezun Öğrencilerin Eğitim Aldıkları Alanlara Göre Dağglımı

\begin{tabular}{lc}
\hline Eğitim Görülen Alan & $f$ \\
\hline Genel Zihinsel Yetenek & 12 \\
Resim & 1 \\
Müzik & 2 \\
Toplam & 15 \\
\hline
\end{tabular}

Öğrencilerin 1'i Resim alanında, 2'si Müzik alanında ve 12 öğrenci Genel Zihinsel Yetenek alanında eğitim almıştır. 


\section{Çalışma Grubu 2 (Veliler)}

İkinci çalışma grubunu çocuğu Bilim ve Sanat Merkezinden eğitim almış ve mezun olmuş veliler oluşturmuştur. Gönüllülük esasına dayanarak random yolla seçilen 11 veli ile görüşme yapılmıştır. Velilerin cinsiyet dağılımı tablolaştııılarak verilmiştir.

Tablo 3: Velilerin Cinsiyete Göre Dağılımı

\begin{tabular}{lc}
\hline Cinsiyet & $f$ \\
\hline Kadın & 4 \\
Erkek & 7 \\
Toplam & 11 \\
\hline
\end{tabular}

Araştırmaya katılan velilerin 7'si erkek 4'ü kadınlardan oluşmuştur.

\section{Veri Toplama Aracı}

Çalışmada araştırmacı tarafından hazırlanan yarı yapılandırılmış görüşme formu kullanılmıştır. Görüşme formu yaklaşımı, görüşme sırasında irdelenecek bir sorular veya konular listesini kapsar. Görüşmeci önceden hazırladığı konu veya alanlara sadık kalarak hem önceden hazırlanmış soruları sorma, hem de bu sorular konusunda daha ayrıntılı bilgi alma amacıyla ek sorular sorma özgürlüğüne sahiptir (Yıldırım ve Şimşek, 2013). Bilim ve Sanat Merkezlerini birkaç farklı açıdan irdelemeyi ve değerlendirmeyi amaçlayan bu çalı̧̧mada açık uçlu sorular sorularak konu derinlemesine incelenmeye çalışılmıştır. Görüşme formu birincisini kişilerin demografik bilgilerinin istendiği kişisel bilgiler bölümü ve ikincisini ise görüşme sorularının oluşturduğu toplam iki bölümden oluşmaktadır.

İlk bölümde cinsiyet ve BİLSEM'de eğitim görülen alan bilgileri istenmiştir. İkinci bölümü ise yarı yapılandırılmış 6 soru oluşturmuştur. Soruların hazırlanması sürecinde ilgili literatür tarandıktan sonra bir soru havuzu oluşturulmuştur. Sorulardan çalışmanın amacına hizmet edecek sorular seçilerek görüşme soruları belirlenmiştir.

Nitel araştırmalarda Geçerlik / İnanırlık, Güvenirlik / Tutarlılık ve Genellenebilirlik / Nakledilebilirlik sağlamak için verileri sınıflandırmada uzman görüşlerine başvurulmuştur. Araştırmada kullanılan görüşme formunun geliştirilmesinde alan yazın taramasının ardından, hazırlanan form "uygun", "uygun değil" ve "düzeltilmesine yönelik görüşünüz" şeklinde seçenekler ile 5 uzman görüşüne sunulmuştur. Ardından uzmanlardan gelen dönütler doğrultusunda uzman görüş ve önerileri doğrultusunda yönerge ve maddelerin açık ve anlaşılırlığı sağlanmıştır. Uzmanların değerlendirmeleri sonucunda sunulan görüşler dikkate alınarak Yarı Yapılandırılmış Görüşme Formuna son şekli verilmiştir. Uzman görüşü alındıktan sonra uzmanlardan gelen öneriler doğrultusunda gerekli düzeltmeler yapılarak bir pilot görüşme gerçekleştirilmiştir. $\mathrm{Bu}$ pilot görüşmede soruların anlaşılırlılığına dikkat edilmiş ve ardından düzeltmeler yapılarak kullanılmıştır. Uzmanlardan alınan dönütler ve yapılan bir pilot uygulama ile soru formu yeniden düzenlenerek son hali verilmiştir. Görüşmeler 2019 yılı Nisan ayında gerçekleşmiştir. Veriler araştırmacı tarafından gerekli güven ortamı sağlanarak, katılımcı gönüllülüğüne dayalı olarak gizlilik içerisinde elde edilmiştir.

\section{Verilerin Analizi}

Çalışmanın nitel verileri içerik analizi yöntemlerinden kategorisel analiz yoluyla analiz edilmiştir. $\mathrm{Bu}$ araştırmada verilerin analiz sürecinde tespit edilen görüşler, katılımcıların yükledikleri anlamlar dikkate alınarak belirli tema/kategoriler halinde analiz edilip açıklanmıştır. Öğrenci ve velilerinden elde edilen verilerin analizinde şu aşamalar izlenmiştir. Verilerin analizi için öncelikle katılımcılardan elde edilen veriler kodlanmıştır. Kodlamada sıra no 1, 2, 3, öğrenci (Ö), veli (V) şeklinde, cinsiyet kadın (K),erkek (E) şeklinde ve öğrencinin alanı zihinsel ise (Z), 
resim ise $(R)$ ve müzik ise $(M)$ şeklinde kodlanmıştır. Örneğin 2ÖKR kodlaması 2 numaralı kadın resim öğrencisi olarak açıklanabilir.

İçerik analizinde, toplanan verileri açıklayabilecek kavramlara ulaşmak amaçlanır (Yıldırım ve Şimşek, 2005). Bu doğrultuda katılımeı görüşleri, yapılan analiz sonucunda birtakım kategoriler altında gruplandırılmış ve bu kategorilere ilişkin bulgular açıklanarak, orijinal katılımcı ifadeleri ile desteklenmiştir. Yarı yapılandırılmış görüşme formu yoluyla mezun ve veli görüşlerinin toplanmasıyla elde edilen veriler, iki araştırmacı tarafından birbirlerinden bağımsız olarak incelenmiş ve içerik çözümlemesi yapılmıştır. Bu süreçte araştırmacılar, bağımsız olarak görüşme formlarını incelemiş ve her bir soru maddesine ilişkin verilen cevaplardan hareketle kategoriler oluşturulmuştur.

Rastgele yapılan kodlamanın ardından veriler temalara ayrılmış ve ifade ve temaların yer aldığı bir tablo oluşturulmuştur. Tabloya "uygun", "uygun değil" ve "düzeltilmesine yönelik görüşünüz" şeklinde seçenekler eklenerek, alandan 3 uzmanın görüşüne sunulmuştur. Uzmanlardan alınan dönütler çerçevesinde temalar belirlenmiştir. Elde edilen temalara ilişkin veriler tablolar haline getirilerek bulgular halinde sunulmuştur.

\section{Bulgular}

Bilim ve Sanat Merkezlerinindeğerlendirilmesine ilişkin alt problemlerin katılımcı öğrenci ve öğretmen görüşlerine göre analizi yapılarak, tematik içerikli tespitleri içeren tablolar oluşturulmuştur. Bununla birlikte bulgular orijinal katılımcı öğretmen görüşleri ile desteklenerek bu görüşlerin hangi alt grupta yer aldığı gösterilmiştir.

\section{BİLSEM'den Beklentiler}

Katılımcıların BİLSEM'e yönelik beklentilerinin karşılanma düzeylerine ilişkin bulgular tablo 1'de verilmiştir.

Tablo 4: Beklenti Gerçekleşme Düzeyleri

\begin{tabular}{|c|c|c|}
\hline Düzey & $\begin{array}{c}\text { Öğrenci } \\
f \\
\end{array}$ & $\begin{array}{c}\text { Veli } \\
f\end{array}$ \\
\hline Yüksek & 10 & 2 \\
\hline Orta & 4 & 5 \\
\hline Düşük & 1 & 4 \\
\hline
\end{tabular}

Tablo 4 incelendiğinde mezun öğrenciler ve velilerin beklenti düzeylerinde farklılık gözlenmektedir. Beklentilerinin yüksek düzeyde karşılandığını belirten mezunların sayısı 11 iken velilerin sayısı 2'dir. Beklentilerinin orta düzeyde karşılandığını ifade eden mezun öğrenci sayısının 4, veli sayısı ise 5 olduğu görülmektedir. 1 mezun ve 4 veli beklentilerinin karşılanmadığını ya da düşük düzeyde karşılandığını belirtmişlerdir. Beklenti düzeylerine ilişkin orijinal katılımcı görüş örnekleri aşağıdaki gibidir:

[1ÖKM] "Beklentilerimi fazlasıyla karşılayan bir merkezdi."

[6ÖEZ] "Beklentilerim yüksek ölçüde karşılandı ve zaman içerisinde değişmedi."

[13ÖKZ] “...var olan zekâmı boşa kullanmamamı sağlamasıydı fakat ne yazık ki bunlardan uzak, klasik Türk eğitim sistemine uygun sınav-ders odaklı bir eğitim gördüm.”

[7VEİ] “...oldukça yüksek düzeyde karşıladı.” sunulmuştur.

Mezunların ve velilerin BİLSEM'e yönelik beklentilerine ilişkin bulgular Tablo 5'te 
Tablo 5:BİLSEM'den Beklentiler

\begin{tabular}{clcc}
\hline Tema & \multicolumn{1}{c}{ Alt Tema } & Öğrenci & Veli \\
& & $f$ & $f$ \\
\hline & Sınava Hazırlık & 3 & - \\
& Sanat Alanında Kendini Geliştirme & 2 & 1 \\
& Yaratıcı Düşünmeyi Geliştirme & 2 & - \\
& İlgi Alanlarına Yönelik Eğitim Alma & 2 & 4 \\
BİLSEM'den & Farklı Deneyimler Yaşama & 2 & - \\
Beklentiler & Sosyal Beceriler Kazanma & 2 & - \\
& Sosyal Etkinlik Ağılıklı Eğitim & - & 3 \\
& Vizyon Sahibi Olma & - & 1 \\
& İyi Vakit Geçirme & - & 1
\end{tabular}

Tablo 5'te mezun öğrenci ve velilerin beklentilerine ilişkin ifadelerden oluşturulan temalar verilmiştir. Tablo incelendiğinde öğrenci ve velilerin beklentilerinin farklı olduğu gözlenmektedir. İlgi alanlarına yönelik eğitim alma beklentisi veliler tarafından en fazla dile getirilen beklenti olmuştur. Sosyal etkinlik ağırlıklı eğitim de 3 veli tarafindan ifade edilerek 2. Sırada yer almıştır. Mezun öğrencilerin en fazla dile getirdiği beklenti ise sınava hazırlık olmuştur. Sanat alanında kendini geliştirme, yaratıcı düşünmeyi geliştirme, ilgi alanlarına yönelik eğitim alma, farklı deneyimler yaşama ve sosyal beceriler kazanma beklentileri de 2 şer mezun öğrenci tarafindan dile getirilmiştir. Vizyon sahibi olma, iyi vakit geçirme ve sosyal etkinlik ağırlıklı eğitim veliler tarafından ifade edilen beklentiler olurken, öğrencilerin bu beklentilere sahip olmadıkları ortaya çıkmaktadır. Diğer taraftan, sınava hazırlık, yaratıcı düşünmeyi geliştirme, farklı deneyimler yaşama ve sosyal beceriler kazanma gibi beklentiler ise öğrenciler tarafindan dile getirilirken, velilerin bu beklentileri ifade etmediği görülmektedir. Yukarıda verilen temalara ilişkin orijinal katılımc1 görüşleri aşağıdaki gibidir:

[2ÖKM] "Bunlar sosyal becerilerimi geliştirmek, bir müzik aleti çalabilmek ve iyi zaman geçirebilmekti."

[13ÖEZ] "Üniversite sınavına yaklaştıkça doğal olarak beklentilerim biraz daha sinava yönelik eğitime kaydı."

[7VEİ] "bilim ile ilgilenmesi meraklı olmasını yüksek bir vizyona sahip bir birey olmasını bekliyordum ve beklentilerim gerçekleşti."

[4VEÜ] "beklentilerimizi iyi bir düzende karşılamadı. Yeterli gelmedi."

[10VKÜ] "daha fazla uygulama olsaydı daha iyi olabilirdi. Ama genel olarak güzeldi.”

\section{BİLSEM'in Sağladığı Katkılar}

Mezunların ve velilerin BİLSEM'in hangi alanlarda katkı sağladığına yönelik bulgular Tablo 6'da verilmiştir. 
Tablo 6: BİLSEM'in Katkı Sağladığı Alanlar

\begin{tabular}{clcc}
\hline Tema & Alt Tema & Öğrenci & Veli \\
& & $\boldsymbol{f}$ & $\boldsymbol{f}$ \\
\hline BILLSEM'in & Akademik & 12 & 8 \\
Katkı & Sanat & 9 & 1 \\
Să̆ladı̆̆ı & Farklı Alanlar & 3 & - \\
Alanlar & Sosyal & 2 & 8 \\
& Kişisel & - & 7 \\
\hline
\end{tabular}

Bilim ve Sanat Merkezinin öğrencilere hangi alanlarda katkı sağladığına ilişkin bulguların yer aldığı Tablo 6 incelendiğinde; BİLSEM'in kendilerine en fazla akademik alanda katk1 sağladığını belirtmişlerdir. Bunun ardından 9 öğrenci BILSEM'in sanat alanında kendilerine katk1 sağladığını dile getirmişlerdir. 3 öğrenci farklı alanlarda ve 2 öğrenci de sosyal alanda BİLSEM'den katkı sağladıklarını ifade etmişlerdir. Velilerden elde edilen veriler incelendiğinde ise veliler de BİLSEMin çocuklarına akademik ve sosyal alanlarda katkı sağladığını belirtmişlerdir. Kişisel alanda 7 veli katkı sağlandığını dile getirirken bu alanda hiçbir öğrenci katkı sağlandığını ifade etmemişlerdir. Benzer şekilde veliler de farklı alanlarda BíLSEM'den katkı sağladıklarını belirtmemişlerdir.

Temalara ilişkin orijinal katılımcı görüşleri aşağıda verilmiştir:

[3ÖEZ] "Bu öğretmenlerim sayesinde kendimi akademik ve sosyal alanda çok geliştirdiğime inanıyorum."

[1ÖKM] "Sanat dışında her alana ilgi duymamı sağladı."

[8VEÜ] "Soyut düşünmesi gelişti. Özgüven artt1."

[9VEÜ] “Akademik yönden üniversiteye hazırlık için faydalı olduğunu düşünüyorum.”

\section{BİLSEM'in Kişisel, Akademik ve Sosyal Yönlerden Sağladığı Katkılar}

BİLSEM'in öğrencilere ne düzeyde katkı sağladığına ilişkin veli ve mezunlardan alınan verilere ilişkin bulgular Tablo 7'de verilmiştir.

Tablo 7: BİLSEM'in Öğrencilerin Gelişimlerine Sağladığı Katkı Düzeyi

\begin{tabular}{ccc}
\hline Katkı Düzeyi & Öğrenci & Veli \\
& $\boldsymbol{f}$ & $\boldsymbol{f}$ \\
\hline Yüksek & 12 & 5 \\
Orta & 3 & 6 \\
Düşük & - & - \\
\hline
\end{tabular}

Tablo 7'deBİLSEM'in öğrencilerin kişisel, sosyal ve akademik yönlerden gelişimlerine ne derece katkı sağladığına ilişkin veriler yer almaktadır. Öğrenciler en fazla yüksek düzeyde katkı sağlığını belirtirken veliler orta düzeyde katkı sağladığını ifade etmişlerdir. Düşük düzeyde katkı sağladığını ya da hiç katkı sağlamadığını belirten veli ve öğrenci gözlenmemiştir. Yukarıdaki verilere ilişkin orijinal katılımcı görüşleri aşağıdaki gibidir:

[3ÖEZ] "Şu anda kişisel, sosyal ve akademik gelişimimin büyük bir kısmını BİLSEMde bulunduğum süreç içerisinde kazandığıma inanıyorum.” 
[15ÖEZ] "Ben çekingen bir çocuktum. Bana hem kişisel hem sosyal olarak büyük katk1sı oldu."

Tablo 8: Sosyal, Akademik ve Kişisel Gelişime Katkısı

\begin{tabular}{clcl}
\hline Tema & \multicolumn{1}{c}{ Alt Tema } & Öğrenci & Veli \\
& & $\boldsymbol{f}$ & $\boldsymbol{f}$ \\
\hline \multirow{2}{*}{ Sosyal, Akademik ve } & Sosyal Gelişim & 12 & 7 \\
Kişisel Gelişime Katkısı & Kişisel Gelişim & 9 & 6 \\
& Akademik Gelişim & 8 & 5 \\
& Yaratıcı Düşünme ve Üretme & 3 & 1 \\
& Sanat Alanında Gelişim & 1 & 1 \\
\hline
\end{tabular}

Tablo 8'deBİLSEM'in öğrencilere hangi alanlarda katkı sağladığına ilişkin veriler yer almaktadır. Buna göre; 12 mezun öğrenci ve 7 veli, BİLSEM'in en fazla sosyal gelişim alanda katk1 sağladığı belirtmişlerdir. Öğrenciler ve veliler tarafından yine en çok ifade edilen alanlar sırasıyla kişisel gelişim ve akademik gelişim olmuştur. Sanat alanında gelişim sağladığını dile getiren öğrenci ve velilerin sayısı 1'dir. 3 öğrenci ve 1 veli, yaratıcı düşünme ve üretme konusunda katkı sağladığını belirtmişlerdir.

Bu temalara ilişkin orijinal katılımcı görüşleri aşağıdaki gibidir:

[9ÖEZ] "Ancak geçirdiğim tüm o yıllar boyunca oradaki arkadaşlarımla beraber birçok akademik ve sosyal yeterlilik kazandım."

[8ÖKR] "Resim sanatında hocalarım sayesinde çok farklı tarz ve teknikler öğrendim.”

[10VKÜ] "Kendine güven, şehir dışı çalışmalarda sosyal ortamlara girmesi, Türkiye'den pek çok kişi ile tanışması."

[3VEÜ] "Bilim sanat merkezi kişisel açıdan dışa dönük ve sosyal olmamızı sağladı. Akademik anlamda temelimizin sağlam olmasına katkıda bulundu."

\section{Sınav Dönemlerinde BİLSEM}

Öğrencilerin liselere ve üniversiteye geçiş sınavları dönemlerinde BİLSEM'de neler yaşadıklarına ilişkin tecrübeler temalar halinde Tablo 9'da verilmiştir.

Tablo 9: Sinav Dönemlerine İlişkin Bulgular

\begin{tabular}{clcc}
\hline \multicolumn{1}{c}{ Tema } & \multicolumn{1}{c}{ Alt Tema } & Öğrenci & Veli \\
& & $f$ & $f$ \\
\hline \multirow{4}{*}{ Sinav Dönemlerinde } & Sınavlara Takviye & 6 & 3 \\
BİLSEM & Lise Dönemi Klasik Ders Yapılması & 3 & - \\
& Sorunsuz Geçmesi & 2 & - \\
& Sinav Dönemleri Devamsızlık Sorunu & 1 & 4 \\
& Öğrencilerin Derslerde Aktif Olması & - & 1 \\
& Sinav Süreçlerinde Rehberlik Desteği & - & 1 \\
& Sinavlara Katkı Sağlamaması & 1 & - \\
\hline
\end{tabular}

Tablo 9'da BİLSEM sürecinde liselere geçiş ve üniversiteye giriş sınav dönemlerinde öğrenci ve velilerin yaşadıkları olumlu ve olumsuz durumlara ilişkin bulgular yer almaktadır. Buna göre; BİLSEM sınav dönemlerinde sınavlara takviye yapma açısından öğrenciler ve veliler tarafından faydalı bulunmuştur. 3 veli ve 6 öğrenci bu durumu dile getirmişlerdir. $\mathrm{Bu}$ tema 
dışındaki temalarda katılımcıların ortak verdiği cevap bulunmamaktadır. Bunun yanı sıra, bu dönemde BİLSEM'de hiçbir sorun yaşamadığını belirten 2 öğrenci bulunmaktadır.

Olumsuz durumlar incelendiğinde bulunan temalar da yine farkl1lık göstermektedir. Örneğin öğrencilerden 1'iBİLSEM'in sınavlara katkı sağlamadığını belirtmiştir. 3 öğrenci ise lise döneminde BİLSEM'de klasik şekilde ders yapıldığını, okuldan farkı kalmadığını ifade etmiştir. Velilerin yanıtları incelendiğinde, 4 velinin sınav dönemlerinde çocuklarının devamsızlık sorunu yaşadıklarını dile getirdiği görülmüştür. Bununla birlikte, öğrencilerin derslerde aktif olmaları gerektiğini ve sınav süreçlerinde rehberlik desteğinin olması gerektiğini belirten veli sayısı 1 olarak görülmektedir. Tabloda verilen temalara ilişkin orijinal katılımcı görüşleri aşağıda verilmiştir:

[9ÖEZ] "Liseye geçiş sınavı süresince bilim sanata devam ettim ancak bu liseye hazırlanmama engel olmadı. Lakin üniversite sinavına hazırlık sürecinde daha az gittim bilim sanata."

[2ÖKM] "Eğitim programı fena değil diyebilirim. Ancak geliştirilmeye ihtiyaç duyuyor. Örneğin direkt olarak konu anlatmak ve dershane işlevi görmekten ziyade öğrencilerin kişisel gelişimlerini ön plana alan bir yaklaşım BİLSEM'in amacına daha iyi hizmet etmesini sağlayabilir."

[8VEÜ] "Sınav hazırlık dönemlerinde doğrusu pek uğramadı."

[7VEİ] "sadece üniversite sınavına hazırlanırken rehbere ihtiyacı oldu ve bunu Bilim Sanat merkezinde karşıladı. Diğer öğrencilere de rehberlik servisi etkin şekilde kullanmalarını öneririm.”

Sınav dönemlerinde yaşanan olumsuzluklara yönelik veli ve mezun önerilerine ilişkin bulgular Tablo 10'da verilmiştir.

Tablo 10: Sınav Dönemlerine İlişkin Öneriler

\begin{tabular}{|c|c|c|c|}
\hline Tema & Alt Tema & $\begin{array}{c}\text { Öğrenci } \\
f \\
\end{array}$ & $\begin{array}{c}\text { Veli } \\
f\end{array}$ \\
\hline \multirow{3}{*}{$\begin{array}{l}\text { Sinav } \\
\text { Dönemlerine } \\
\text { İlişkin } \\
\text { Öneriler }\end{array}$} & Lise Döneminde Ders Sayısı Artırılması & 1 & 1 \\
\hline & Lise Döneminde Farklı Dersler Olması & 1 & 1 \\
\hline & Klasik Ders Yerine Proje Odaklı Dersler & 1 & 1 \\
\hline
\end{tabular}

Tablo 10'da katılımcıların sınav dönemlerinde yaşadıkları olumsuzluklara ilişkin sundukları önerilere ait temalar yer almaktadır. Temalar incelendiğinde katılımcıların bütün temalara eşit sayıda aynı yanıtları verdikleri görülmektedir. Ortaya çıkan temalar şu şekildedir; lise döneminde ders sayısı artırılabilir, lise döneminde farklı dersler olabilir ve klasik ders yerine proje odaklı dersler olabilir. Bu temalar birer öğrenci ve veli tarafindan belirtilmiştir. Verilen önerilerin hepsi lise dönemi için verildiğinden, lise döneminde BİLSEM'in işleyişinde bazı sorunların var olduğu söylenebilir.

Temalara ilişkin orijinal katılımcı görüşleri aşağıdaki gibidir:

[4ÖKZ]"Sınav hazırlık dönemlerimde BİLSEM'in faydasını gördüm ancak daha önce de bahsettiğim gibi alabileceğimiz ders sayısının 1'e indirilmesi bence olumsuz bir şeydi. Daha fazla ders alma imkânımız olsaydı sınava hazırlığımız için daha etkili bir kurum olabilirdi. 
[2ÖKM] "Örneğin direkt olarak konu anlatmak ve dershane işlevi görmekten ziyade öğrencilerin kişisel gelişimlerini ön plana alan bir yaklaşım BİLSEM'in amacına daha iyi hizmet etmesini sağlayabilir. Bunu ulusal ve uluslararası projelerle, işbirlikleriyle ve okul/dershane mantığından ya da kolaya kaçan öğretmenlerin geliştirilmesi yoluyla yapabilirlerdi."

[6VEÜ] "Bilim sanat merkezleri dersane olarak düşünülürse öğrenciler başarılı olmamazlar."

[3VEÜ] "Devam eden öğrencilerin daha çok dersten yararlanması daha iyi olurdu."

\section{BİLSEM'de Devamsızlık Sorunu}

Öğrencilerin BİLSEM'e devamsızlık yapma nedenlerine ilişkin bulgular Tablo 11'de verilmiştir.

Tablo 11: Devamsızlık Nedenleri

\begin{tabular}{clcc}
\hline Tema & \multicolumn{1}{c}{ Alt Tema } & Öğrenci & Veli \\
& & $\boldsymbol{f}$ & $\boldsymbol{f}$ \\
\hline \multirow{3}{*}{ Devamsızlık Sorunu } & Sinav Maratonu & 4 & 1 \\
& Yoğunluk & 2 & 1 \\
& BİLSEM'in Okula Benzemesi & 1 & - \\
& Okul Sinavları & 1 & - \\
& Lise Dönemi Devamsılık & - & 3 \\
& Yatılı Okulda Okuma & 1 & - \\
\hline
\end{tabular}

Öğrencilerin BİLSEM'e devam ederken yaşadıkları bazı olumsuzluklar devamsızlık yapmalarına neden olmaktadır. Tablo 11 incelendiğinde, öğrenci ve velilerin farklılık ve benzerlik gösterdiği durumlar görülmektedir. Sınav maratonundan dolayı devamsızlık yaptı̆̆ını söyleyen öğrenci sayısı 4 iken veli sayısı 1'dir. Yaşadığı yoğunluk temasını 2 öğrenci ve 1 veli dile getirmiştir. Farklılık gösteren temalara bakıldığında, öğrenciler, BİLSEM'in okula benzemesi, okul sınavları ve yatılı okulda okuma durumlarından dolayı devamsızlık sorunu yaşadıklarını ifade etmişlerdir. Veliler ise devamsızlığın lise döneminde yapıldığını belirtmişlerdir. Sınav dönemleri ve öğrencilerin yaşadığı yoğun süreçlerin BİLSEM'e devam konusunda sıkıntılara neden olduğu söylenebilir.

Verilen temalara ilişkin orijinal katılımcı görüşleri aşağıda verilmiştir:

[8ÖKR] "Zaman ilerledikçe hem dersler çakıştığından hem de fiziksel yorgunluğa sebep olduğundan maalesef katılımım git gide azaldı"

[13ÖKZ] "Bir süre sonra herhangi bir etüt merkezinden farkı kalmadığını ve okul derslerinden farklı bir şeyler öğrenmediğimi görünce gelmek için isteğim azaldı ve dersler, sınavlar tuzu biberi olarak BİLSEM'e gelişlerim gittikçe seyrekleşti.”

[11ÖEZ] "Haftalık 70 saat civarı derse girmek beni çok yorduğu için son sene pek devam edemedim."

[9VEÜ] “derslerin çok yoğun geçtiği lise eğitiminden sonra birde BİLSEMe gelmek öğrenciyi zorlar tabi ki."

[4VEÜ] "ilkokul çağında devam ediyorlar lise çağında devamsızlık artıyor.”

Tablo 12'de öğrencilerin yaşadıkları devamsızlık sorununa yönelik mezunlar ve velilerin önerilerine yer verilmiştir. 


\begin{tabular}{|c|c|c|c|}
\hline Tema & Alt Tema & $\begin{array}{c}\text { Öğrenci } \\
f\end{array}$ & $\begin{array}{c}\text { Veli } \\
f\end{array}$ \\
\hline \multirow{7}{*}{$\begin{array}{c}\text { Devamsizlık } \\
\text { İçin } \\
\text { Öneriler }\end{array}$} & Öğretmen Sayısı Artırılması & 1 & 1 \\
\hline & Ders Bitişi Öğrenci Servisleri & 1 & - \\
\hline & Okula Dönüştürülmesi & 1 & - \\
\hline & Lise Dönemi Ders Sayısının Artması & - & 1 \\
\hline & Öğretmen Seçiminde Daha Titiz Olunması & - & 1 \\
\hline & $\begin{array}{l}\text { Ders Yerine Proje Odaklı Çalışmalar } \\
\text { Yapılması }\end{array}$ & - & 1 \\
\hline & Ders Sürelerinin Kısaltılması & 1 & 1 \\
\hline
\end{tabular}

Tablo 12'deBİLSEM'de öğrencilerin devamsızlık yapmamaları için katılımcılardan alınan öneriler sunulmuştur. Tablo incelendiğinde öğrenciler, öğretmen sayısının arttırılmasını, ders bitişi öğrenci servislerinin olmasını ve BİLSEM'in okula dönüştürülmesini önermişlerdir. Veliler de öğretmen sayısının arttırılması konusunda öğrencilerle hemfikirdirler. Bunun dışında öğrencilerinkinden farklı öneriler sunmuşlardır. Bunlar; lise dönemi ders sayısının artması gerektiğini, öğretmen seçiminde daha titiz olunması gerektiğini, ders yerine proje odaklı çalışmalar yapılması gerektiğini ve ders sürelerinin kısaltılmasını önermişlerdir. Yukarıda verilen temalara ilişkin örnek ifadeler aşağıdaki gibidir:

[11ÖEZ] "Haftalık 70 saat civarı derse girmek beni çok yorduğu için son sene pek devam edemedim. Ders saatleri biraz daha ileri alınıp ders süreleri kısaltılabilir.”

[8ÖKR] "Zaman ilerledikçe hem dersler çakıştı̆̆ından hem de fiziksel yorgunluğa sebep olduğundan maalesef katılımım git gide azaldı. BILLSEM ders programı zaten çoğunlukla ögrenciye göre ayarlanıyordu. Önerim belki akşam dönüşte servis aracı ayarlanması olabilir."

[5VKÜ] "Bu konuda alanında yetkin ve etkin hocalarla öğrencileri ders yapmaya, öğrenmeye, ders hakkında merak uyandıracak şekilde onların katılımları sağlanmalıdır."

[3VEÜ] "Lisede fizik, kimya, biyoloji de almak isterdik. Özellikle 11 ve 12 'de sadece tek ders matematik alabildik."

\section{Öneriler}

Mezunların ve velilerin BİLSEM'lerin daha etkin hale gelmelerine ilişkin sunduğu önerilere tablo 13 'te yer verilmiştir.

Tablo 13:Öneriler

\begin{tabular}{llcc}
\hline Tema & \multicolumn{1}{c}{ Alt Tema } & Öğrenci & Veli \\
& Okul Öğretmenleri ile İşbirliği Yapılaması & $f$ & $f$ \\
\hline \multirow{6}{*}{ Öğretmen Seçiminde Belli Kriterler Olması } & - & 1 \\
& Öğrenci Sayısının Azaltılması & - & 5 \\
& Öğretmen-Veli İşbirliğinin Sağlanması & - & 1 \\
& Bi்LSEM Mezunu Olmanın Akademik Bir Getirisi Olması & - & 1 \\
& Fiziki Şartların İyileştirilmesi & 1 & 1 \\
& Devamsılık Konusunda Yaptırımlar Olması & - & 1 \\
& Projelere Ağırlık Verilmesi & 5 & 1 \\
& Mezun Mentorluğu & 1 & - \\
& Lise Döneminin Daha Etkin Olması & 3 & - \\
& BİLSEM Eğitiminin Hayat Boyu Olması & 2 & - \\
& Sosyal Etkinliklerin Artırılması & 3 & - \\
\hline
\end{tabular}

Turkish Studies -Education, 15(3) 
Bilim ve Sanat Merkezlerinin daha etkin olabilmesi için katılıcımlardan önerileri alınmıştır. Öneriler temalar halinde tablo 13 'te verilmiştir. Tablo incelendiğinde veli ve öğrencilerin önerilerinin çoğunlukla farklı olduğu gözlenmektedir. Fiziki şartların iyileştirilmesi gerektiğini 1 öğrenci ve 2 veli önermiştir. Ayrıca projelere ağırlık verilmesini öneren 5 öğrenci ve 1 veli bulunmaktadır. Bu iki tema dışındakiler yalnızca veli ya da öğrencileri tarafından dile getirilmiştir. Öğrencilerin önerileri lise döneminin daha etkin olması, sosyal etkinliklerin artırılması, BİLSEM eğitiminin hayat boyu olması ve mezun mentorluğu olarak sıralanmaktadır. Öneriler lise dönemi ve sonrasını kapsadığı söylenebilir. Yalnızca velilerin sunduğu öneriler ise şöyle sıralanabilir; öğretmen seçiminde belli kriterler olması, okul öğretmenleri ile işbirliği yapılması, öğrenci sayısının azaltılması, öğretmen-veli işbirliğinin sağlanması, BİLSEM mezunu olmanın akademik bir getirisinin olması ve devamsızlık konusunda yaptırımların olması. Verilen önerilere ilişkin orijinal katılımcı görüşleri aşağıda verilmiştir:

[12ÖEZ] “Ayrıca sadece proje ve olimpiyat eğitimine yoğunlaşırlarsa öğrencilere okul eğitiminden daha yararlı bir vizyon katabileceklerini düşünüyorum.”

[10ÖKZ] "Mezunlar için de bir organizasyon bulunmalı ve mezunların da bazı aktivitelerde yer alması sağlanmalı."

[5ÖKZ] "Yukarda da belirttiğim gibi BİLSEM'in ilk ve ortaokul eğitimini beğeniyorum. Ama lise eğitimi açısından daha verimli hale getirilebilir."

[10VKÜ]“Öğretmen kalitesi yükseltilmeli. Devam konusunda yaptırımlar olabilir. Daha kapsamlı fiziksel donanımlı bir bina olabilir."

[9VEÜ]"Öğretmenlerinin daha iyi eğitimle seçildiği, deney ve araştırmaların yoğun olduğu ve sonunda öğrenciye akademik yönden bir ayrıcalığın verilmesi gerektiği aksi halde bugünkü haliyle zaman israfı gibi görünen bir kurs."

[1VKÜ] "Öğretmenlerin gerekli eğitimleri alması. Öğretmen veli işbirliğinin sürekliliğinin sağlanması.”

\section{Sonuç ve Tartışma} verilmiştir.

Araştırma bulgularına dayalı olarak oluşturulan çıkarsama şematik olarak Şekil 1'de 


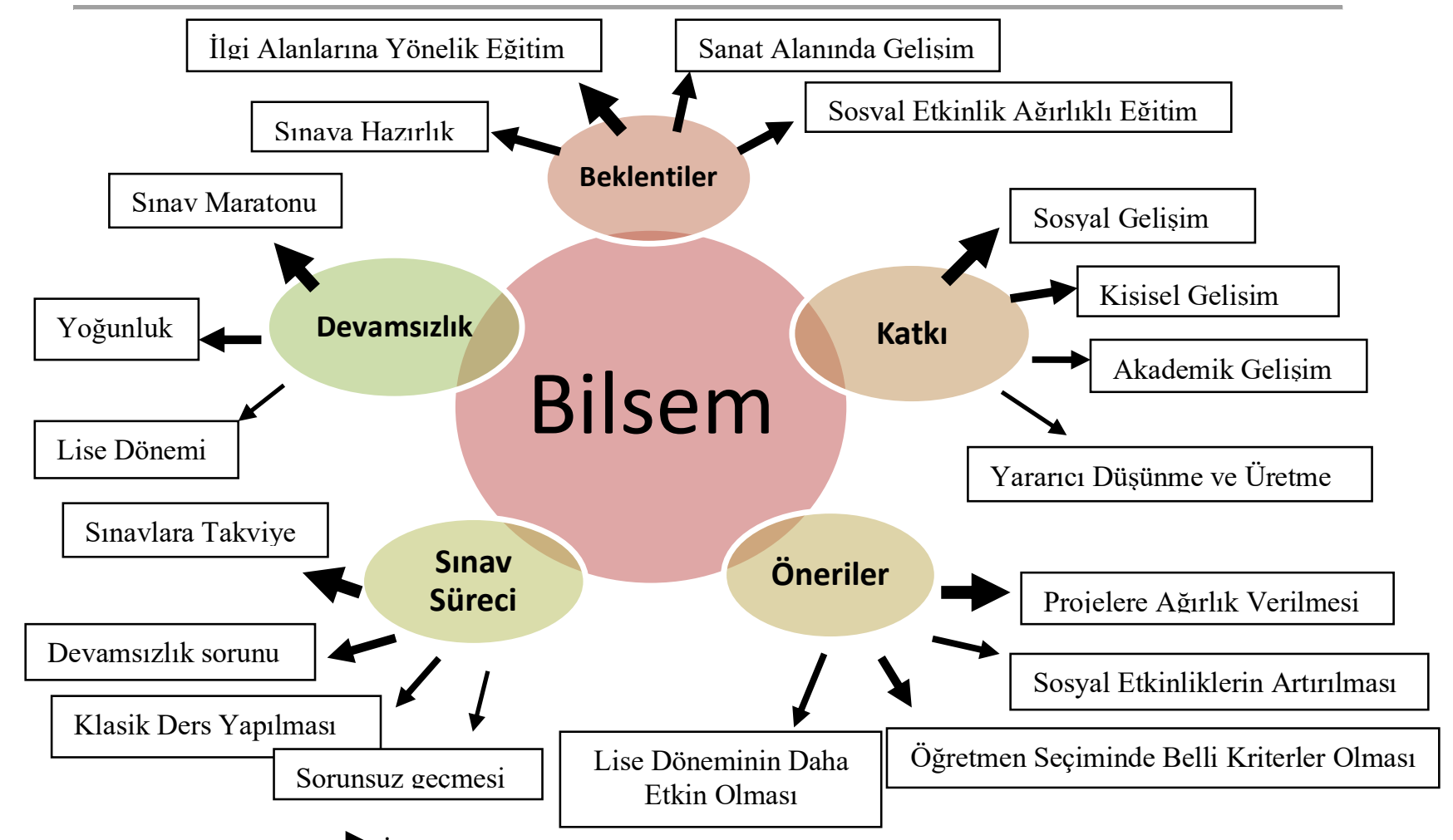

Kuvvetli vurgu( $\longrightarrow$ ilgi alanlarına yönelik eğitim, sınav maratonu, sınavlara takviye, sosyal gelişim, projelere ağırlık verilmesi.

Yüksek vurgu $(\rightarrow$ ) Sosyal etkinlik ağırlıklı eğitim, sınava hazırlık, sanat alanında gelişim, yoğunluk, sınav dönemleri devamsızlık sorunu, kişisel gelişim, öğretmen seçiminde belli kriterler olması.

Orta vurgu ( $\rightarrow$ ) Lise dönemi klasik ders yapılması, lise döneminin daha etkin olması, sosyal etkinliklerin artırılması, akademik gelişim, lise dönemi.

Zayıf vurgu ( $\rightarrow$ ) Sorunsuz geçmesi, yaratıcı düşünme ve üretme.

(Frekans değerleri esas alınmıştır.)

Şekil 1:BİLSEM’e Dönük Bütüncül Bakış Şeması

Bilim ve Sanat Merkezlerini çok boyutlu olarak inceleyen araştırmada ilk olarak öğrenci ve velilerin Bilim ve Sanat Merkezinde eğitim almaya başlamadan önceki beklentilerinin neler olduğu ve bu beklentilerinin karşılanma düzeylerine ilişkin elde edilen bulgular çerçevesinde hem veli hem de mezunlar büyük oranda beklentilerinin yüksek düzeyde karşılandığı görülmektedir. Bu konuda öğrencilerin beklentileri daha çok sınava hazırlık konusunda destek alma isteğinde oldukları görülmektedir. Ayrıca sanat alanında kendini geliştirme, yaratıcı düşünmeyi geliştirme, ilgi alanlarına yönelik eğitim alma, farklı deneyimler yaşama ve sosyal becerilerini geliştirme de öğrenciler tarafından dile getirilen beklentiler olmuştur. Bunlara karşın katılımcı velilerin beklentileri incelendiğinde, velilerin çoğunluğu çocuklarının ilgi alanlarına yönelik eğitim almalarını beklemektedirler. Benzer şekilde, Karakuş BILLSEM velileri ile yürüttüğü çalışmasında (2010) anne babaların çocuklarının ilgi ve yetenekleri doğrultusunda eğitim görmeleri ve yönünde beklentilerinin olduğu saptamıştır. Velilerin diğer beklentileri ise, sanat alanında kendini geliştirme, sosyal etkinlik ağıllıklı eğitim, vizyon sahibi olma ve iyi vakit geçirme olarak sıralanmaktadır. Genel olarak ise, veliler çocuklarının akademik alan dışında farklı alanlarda da kendilerini geliştirmelerine firsat sunacak bir eğitim almaları beklentisi içindedirler.

Veli ve mezunlar BİLSEM'in öğrencilere yüksek düzeyde katk1 sağladığı görüşündedirler. Mezunların 12'si ve velilerin ise 5'iBILLSEM'den yüksek düzeyde katkı sağladığını belirtirken, orta düzeyde katkı sağladığını düşünen 3 öğrenci ve 6 veli bulunmaktadır. Öğrencilerin BİLSEM 
memnuniyetinin velilerinkinden daha fazla olduğu ifade edilebilir. Ayrıca veliler ve mezunlar BİLSEM'in sosyal, kişisel, akademik, yaratıcı düşünme ve üretme ve sanat alanında gelişimlerine katk1 sağladığını dile getirmişlerdir. En fazla katkı sağlanan alan sosyal gelişim olmuştur. BILLSEM'de okul dışında farklı bir ortama giren öğrencilerin, burada farklı yaştan öğrencilerle birlikte ders işleme olanağına sahip olmakta ve ders aldıkları gruplar değişiklik gösterebilmektedir. $\mathrm{Bu}$ durumun, onların sosyal gelişimlerine katkı sağladığı sonucuna varılabilir. Bu sonuçlar, Sarılaş vd. (2019); Yumuş ve Toplaş (2011); Yıldız (2011) ve Şahin (2014) bulgularında, velilerin BİLSEM'lerin yaratıcılık, kişisel ve sosyal gelişim açısından öğrencilere katkı sağladığı sonuçlarını desteklenmektedir.

Mezunların ve velilerin liselere geçiş ve üniversiteye giriş sınavlarına hazırlandıkları dönemlerde BİLSEM'de neler yaşadıklarına ilişkin görüşlerinden öğrencilerin yarıya yakınının hazırlandıkları sınava takviye amacıyla BILSEM' e geldikleri ortaya çıkmıştır. Sınava hazırlık amacıyla gelen öğrenciler aynı zamanda bu dönemlerde BİLSEM'de klasik tarzda ders işlenmesinden de şikâyet etmektedirler. Bunun yanı sıra öğrencilerden BİLSEM'in sınava katkı sağlamadığını ve sınav dönemlerinin sorunsuz geçtiğini belirtenler de bulunmaktadır. Buna göre, sınav dönemlerinde BİLSEM'den sınavlara takviye amaçlı ders görmek isteyenlerin olmasına rağmen bu durumdan rahatsız olanların da bulunduğu söylenebilir. Sınav dönemlerinde ders işlemek yerine daha çok proje ve sosyal etkinliklerde yer almak isteyen öğrenciler de bulunmaktadır.

Sınav dönemlerinde mezun ve velilerin BİLSEM'in işleyişine yönelik önerileri incelendiğinde ise önerilerin hepsinin lise dönemini kapsadığı görülmektedir. Katılımcılar lise döneminde ders sayısının artırılmasını ve farklı derslerin de bulunması önerilerinde bulunmuşlardır. BİLSEM'de eğitim alan öğrenciler lise dönemine denk gelen proje döneminde en fazla 2 ders seçimi yapabilmektedirler. Okul derslerinin yoğunluğu ve sınava hazırlık süreçlerinden dolayı bu sayı genellikle 1 ders saatine düşebilmektedir. BİLSEM'de gerçekleştirilen bütün etkinliklerin temelinde proje üretme ve geliştirme çalışmaları esas alınır (MEB, 2019). Bu durumda öğrencilerin aldığı derste sınavlara takviye yapılmasından ziyade proje üretmeleri beklenmektedir. Elde edilen bulgulara dayanarak BILLSEM'de lise döneminde yürütülen uygulamaların gözden geçirilmesi gerektiği sonucuna varılabilir.

BİLSEM'e devam etme konusunda sorun yaşanmadığını belirtenlerin yanı sıra birçok nedenden dolayı devamsızlık yapmak zorunda kalan öğrencilerin de olduğu ortaya çıkmıştır. Devamsızlık nedenleri incelendiğinde ise genellikle lise döneminde öğrencilerin yaşadıkları yoğun ders dönemi, sınava hazırlık, BİLSEM'de okuldaki gibi ders işlenişi, okul sınavları ve yatılı okulda okuma gibi sorunlar olduğu belirtilmiştir. Daha önce yapılan araştırmalar da bu bulguyu destekler niteliktedir. Benzer çalışmalarda Karakuş (2010), Kazu ve Şenol (2012), Sarı ve Öğülmüşs (2014), Güneş (2018), Sarıtaş vd. (2019) öğrencilerin okul yoğunluğu, sınava hazırlık, ulaşımdaki sıkıntılar gibi sebeplerden dolayı BİLSEM'e devam etme konusunda sıkıntılar yaşadıkları bulguları ile paralellik göstermektedir. $\mathrm{Bu}$ soruna ilişkin katılımcılar ders saatlerinin kısaltılması, ders çıkışlarında öğrenci servisinin olması, BİLSEM'in okula dönüştürülmesi ve ders yerine proje odaklı çalışmaların yapılması önerilerinde bulunmuşlardır.

Çalışmada BİLSEM'lerin daha etkin şekilde işlemesi için veli ve mezunlar farklı önerilerde bulunmuşlardır. Her iki katılımcı gruptan ancak "fiziki şartların iyileştirilmesi ve projelere ağırlık verilmesi" şeklindeki iki öneri ortak boyutlu olarak ortaya çıkmıştır. Bunlardan fiziki şartların iyileştirilmesi bulgusu daha önce yapılan birçok çalışmayla da desteklenmektedir (Keskin vd., 2013; Karakuş, 2010; Kazu ve Şenol, 2012; Kaya, 2013). Lise döneminin daha etkin olması, sosyal etkinliklerin artırılması, mezun mentorluğu ve BİLSEM eğitiminin hayat boyu olması, mezunların sunduğu diğer öneriler olarak görülmektedir. Öğrencilerin BİLSEM eğitiminin lise mezuniyetinden sonra da devam etmesini istemeleri, BİLSEM'i benimsedikleri ve olumlu bir yaşantıya sahip 
oldukları şeklinde yorumlanabilir. Lise döneminin daha etkin olması önerisi de daha önce de belirtildiği gibi bu dönemdeki uygulamaların revize edilmesi gerektiğini işaret ettiği söylenebilir.

BİLSEM'in daha etkin hale gelmesine dönük katılımcı önerilerinde, veliler en çok öğretmen seçiminde belli kriterlerin olması gerektiğini dile getirmektedirler. BİLSEM'e öğretmen seçimi Millî Eğitim Bakanlığı İnsan Kaynakları Genel Müdürlüğ̈̈ ile Genel Müdürlük tarafından belirlenen atama ölçütleri doğrultusunda yayımlanan kılavuz hükümlerine göre Bakanlıkça yürütülür (MEB, 2019). Elde edilen bulgulara göre, öğretmen atamasında MEB tarafindan belirlenen belli ölçütler olmasına rağmen, öğretmenlerin özel yetenekli öğrencilerle çalışmaları ve onlara rehber olabilmeleri için bazı eksiklikleri olduğu sonucuna varılabilir. Sarıtaş vd. (2019) BİLSEM velileri ile yürüttükleri çalışmada BİLSEM öğretmenleri seçiminde daha titiz olunması ve öğretmenlerin özel yeteneklilerle çalışma konusunda eğitim almaları gerektiği sonucunu ortaya koymuşlardır. Velilerin diğer önerileri şu şekilde sıralanmaktadır: Okul öğretmenleri ile işbirliği yapılması, öğrenci sayısının azaltılması, öğretmen veli işbirliğinin sağlanması, BİLSEM mezunu olmanın akademik bir getirisi olması ve devamsızlık konusunda yaptırımlar olması.

Veli ve öğrencilerin BİLSEM'e dönük değerlendirmeleri ele alındığında, hem öğrencilerin hem de velilerin çoğunlukla lise dönemindeki uygulamalardan memnun olmadıkları görülmektedir. İlkokul ve ortaokul dönemlerindeki beklentilerinin karşılandığ birçok sorun olduğu görülmektedir. Sınava hazırlanan öğrencilerin sınava hazırlık konusunda yapılan çalışmaları o süreçte doğru bulmakta ancak mezun olduktan sonra ise eleştirmektedirler.

\section{Öneriler}

- Sosyal etkinlikler artırılarak, öğrencilerin bu konudaki ihtiyaçlarına yönelik çalışmalar yapılabilir.

- Proje çalışmalarına ağırlık verilebilir. Öğrencilerin bilimsel araştırma uygulama bilgi ve becerileri geliştirilebilir.

- BİLSEM'e öğretmen alımında belirlenen kriterler genişletilerek özellikle özel eğitim alanında tecrübeli öğretmenlerin seçimi öncelikli olabilir.

- BİLSEM'in fiziki şartları gözden geçirilebilir ve daha donanımlı ortamlar sağlanarak öğrencilerin BİLSEM'den üst düzeyde faydalanmaları sağlanabilir.

- BİLSEM-okul işbirliğigeliştirilere, öğrencilerin okullarındaki öğretmenleri ile işbirliği yapılabilir ve böylece öğrencilerin motivasyonları artırılabilir.

- Lise dönemini öğrencilerin daha aktif ve üretken geçirebilmeleri için proje ve etkinlikler yaparak geçirmeleri sağlanabilir. Sınav stresinden uzaklaşmalarına yardımcı olunabilir ve katıldıkları sosyal etkinliklerle sosyal gelişimlerine daha fazla katkı sağlanabilir.

- Lise döneminde proje döneminde (ÖYG) bulunan öğrencilerin birden fazla ders seçmelerine imkân sağlanabilir. Öğrencilerin ilgi ve yetenekleri doğrultusunda seçecekleri derslerle, lise dönemini daha verimli geçirmelerini sağlanabilir.

- Lise döneminde yaşanan devamsızlık sorununu okul-veli- BİLSEM işbirliğini güçlendirerek çözmeye çalışılabilir.

- Öğrenci ve velinin önerileri doğrultusunda uygulanmakta olan program gözden geçirilebilir.

- Lise döneminde yaşanan devamsızlık, ders sayısının az oluşu, daha çok sınava hazırlık şeklinde işlenen dersler gibi sorunlar veli ve mezunlar tarafından sıkça dile getirilmektedir. $\mathrm{Bu}$ nedenle BILLSEM'de lise döneminde uygulanan eğitim programı tümüyle gözden geçirilebilir. Çalışmada bu soruna ilişkin veli ve 
mezunlar tarafindan sunulan öneriler dikkate alınarak yeni bir program hazırlanabilir.

- Çalışma mezun ve mezun olan öğrencilerin velileri ile yürütülmüştür ve Kırşehir Yusuf Demir BİLSEM ile sinırlıdır. Türkiye genelinde bütün BİLSEM'leri kapsayacak şekilde farklı çalışmalar yürütülebilir.

\section{Kaynakça}

Ataman, A. (2003). Üstün yetenekli/zekâlı çocuk ile yaşamak. Bilim ve Aklın Aydınlı̆̆ında Ĕ̈itim, C. IV, S. 40: s. 15-20.

Bedur, S., Bilgiç, N., \&Taşlıdere, E. (2015). Özel (üstün) yetenekli öğrencilere sunulan destekeğitim hizmetlerinin değerlendirilmesi. HAYEF: Journal of Education, C. XII, S. 1: s.159-175.

Bildiren, A. (2013). Üstün yetenekli öğrencilerin öğrenme stillerinin incelenmesi. Üstün Yetenekliler Eğitimi ve Araştırmaları Dergisi (UYAD), l(1).

Chan, D. W. (2001). Characteristics and competencies of teachers of gifted learners: The Hong Kong teacherperspective. Roeper Review, C. XXIII, S. 4: s. 197-202. https://doi.org/10.1080/02783190109554098

Coleman, L. J., Micko, K. J., \& Cross, T. L. (2015). Twenty-fiveyears of research on thelived experience of being gifted in school: Capturing the students' voices. Journal for the Education of the Gifted, C. XXXVIII, S. 4: $\quad$ s. 358-376. https://doi.org/10.1177/0162353215607322

Çavuşoğlu, M., \& Semerci, N. (2015). Anne babaların BİLSEM'e devam eden özel yetenekli çocuklarına ilişkin görüşleri (Bartın İli Örneği). Bartın Üniversitesi Eğitim Fakültesi Dergisi, s. 325-335. https://doi.org/10.14686/buefad.2015usosozelsayi13220

Çelik-Sahin, Ç. (2014). Bilim ve Sanat Merkezi ögrencilerinin bu kurumlara ilişkin görüşlerinin incelenmesi. Hasan Ali Yücel Ë̆itim Fakültesi Dergisi, C. XI, S. 1: s. 101.

Greenan, J. P., Wu, M., \&Broering, K. (1995). Talented students in career, vocational, and technical education programs. In The Educational Forum (C. LIX, S. 4: s. 409 422). Taylor \& Francis Group.https://doi.org/10.1080/00131729509335073

Güneş, A.(2018). Türkiye'de Bilim Sanat Merkezleri. Avrasya Sosyal ve Ekonomi Araştırmaları Dergisi, C. V, S. 6: s. 185-193.

Hökelekli, H., \& Gündüz, T. (2004). Üstün yetenekli çocukların karakter özellikleri ve değerler eğitimi. I. Türkiye Üstün Yetenekli Çocuklar Kongresi Bildiriler Kitab1 https://doi.org/10.14527/9786053640967.09

Karakuş, F. (2010). Üstün yetenekli çocukların anne babalarının karşılaştıkları güçlükler. Mersin Üniversitesi Eğitim Fakültesi Dergisi, C. $\quad$ VI, $\quad$ S. $\quad$ 1: $\quad$ s. $127-144$. https://doi.org/10.17860/efd.98468

Karasar, N. (1984). Bilimsel araştırma metodu. Hacettepe Taş Kitapçı1ık.

Kaya, N. G. (2013). Education of gifted students and BİLSEM's. Journal of EducationFaculty, C. $X V$, S. 1: s. 115-122.

Kazu, İ. Y., \& Şenol, C. (2012). Üstün yetenekliler eğitim programlarına ilişkin öğretmen görüşleri (BİLSEM örneği). E-Uluslararası Eğitim Araştırmaları Dergisi, 3(2), 13-35. 
Keskin, M. Ö., Samanc1, N. K., \& Aydın, S. (2013). Scienceand art centers: current status, problems, and solution proposals. Journal of Gifted Education Research, C. I, S. II: s.7896.

MEB (2013). Özel Yetenekli bireylerin Eğitimi Strateji ve Uygulama Kılavuzu. https://orgm.meb.gov.tr/meb_iys_dosyalar/2013_11/25034903_zelyeteneklibireylerineitistr atejiveuygulamaklavuzu.pdf

MEB (2018). BİLSEM Yönergesi. https://orgm.meb.gov.tr/meb_iys_dosyalar/2016_10/07031350_BILLSEM_yonergesi.pdf.

Poiner, J. (2018). Gifted education in Ohio: An overview. Thomas B. FordhamInstitute.

Sarı, H., \&Öğülmüş, K. (2014). Bilim ve Sanat Merkezlerinde karş1laşılan sorunların öğretmen ve öğrenci görüşleri açısından değerlendirilmesi. Uluslararası Türk Eğitim Bilimleri Dergisi, C. II, S. 2:s. 254-265. https://doi.org/10.23863/kalem.2017.62

Sarıtaş, E., Şahin, Ü., \& Çatalbaş, G. Velilerin gözüyle BİLSEM. Eğitimde Nitel Araştırmalar Dergisi, C. VII, S. 1: s. 114-133.

Tebliğler Dergisi. (2001). Bilim ve Sanat Merkezleri Yönergesi.

Toptaş, V., \& Yumuş, A. (2011). Bilim ve Sanat Merkezlerinin amacına uygun işleyişinin değerlendirilmesi. Mersin Üniversitesi Ĕgitim Fakültesi Dergisi, C. VII, S. 2: s.80-88.

Vantassel-Baska, J. (2018). American policy in gifted education. Gifted Child Today, C. XLI, S. 2: s. 98-103. https://doi.org/10.1177/1076217517753020

Walsh, R. L., \&Jolly, J. L. (2018). Gifted education in theAustralian context. Gifted Child Today, C. XLI, S. 2: s. 81-88. https://doi.org/10.1177/1076217517750702

Yıldırım, A., \& Şimşek, H. (2013). Sosyal bilimlerde nitel araştırma yöntemleri. Seçkin Yayıncılık. 